\title{
Article \\ Aerobic Fitness, B-Vitamins, and Weight Status Are Related to Selective Attention in Children
}

\author{
Lauren B. Raine ${ }^{1, * \mathbb{D}}$, Jennifer N. H. Watrous ${ }^{2}$, Katherine McDonald ${ }^{2}$, Nicole E. Logan ${ }^{2} \mathbb{D}$, Naiman A. Khan ${ }^{3} \mathbb{D}$, \\ Arthur F. Kramer 2,4 ${ }^{(D)}$ and Charles H. Hillman 1,2 \\ 1 Department of Physical Therapy, Movement, \& Rehabilitation Sciences, Northeastern University, \\ Boston, MA 02115, USA; c.hillman@northeastern.edu \\ 2 Department of Psychology, Northeastern University, Boston, MA 02115, USA; \\ j.hunt@northeastern.edu (J.N.H.W.); mcdonald.kath@northeastern.edu (K.M.); \\ logan.n@northeastern.edu (N.E.L.); a.kramer@northeastern.edu (A.F.K.) \\ 3 Department of Kinesiology and Community Health, University of Illinois at Urbana-Champaign, \\ Urbana, IL 61801, USA; nakhan2@illinois.edu \\ 4 Beckman Institute, University of Illinois at Urbana-Champaign, Champaign, IL 61801, USA \\ * Correspondence: 1.raine@northeastern.edu
}

check for updates

Citation: Raine, L.B.; Watrous, J.N.H. McDonald, K.; Logan, N.E.; Khan, N.A.; Kramer, A.F.; Hillman, C.H Aerobic Fitness, B-Vitamins, and Weight Status Are Related to Selective Attention in Children. Nutrients 2022, 14, 201. https:// doi.org/10.3390/nu14010201

Academic Editor: Roberto Iacone

Received: 9 December 2021

Accepted: 28 December 2021

Published: 31 December 2021

Publisher's Note: MDPI stays neutral with regard to jurisdictional claims in published maps and institutional affiliations.

Copyright: (C) 2021 by the authors. Licensee MDPI, Basel, Switzerland. This article is an open access article distributed under the terms and conditions of the Creative Commons Attribution (CC BY) license (https:// creativecommons.org/licenses/by/ $4.0 /)$

\begin{abstract}
There is an increasing prevalence of poor health behaviors during childhood, particularly in terms of physical activity and nutrition. This trend has occurred alongside a growing body of evidence linking these behaviors to cognitive function. B-vitamins are thought to be particularly important in the neural development that occurs during pregnancy, as well as in healthy cognitive aging. However, much less is known regarding the role of B-vitamins during childhood. Given that preadolescent childhood is a critical period for cognitive development, this study investigated the relationship between specific aspects of nutrition, particularly B-vitamins, and related health factors (e.g., body mass, fitness) on selective attention in children. Children ( $n=85 ; 8-11$ years) completed a selective attention task to assess inhibition. Participant's dietary intake was collected using the Automated Self-Administered 24-h dietary assessment tool. Correlations between specific nutrients, $\mathrm{BMI}$, fitness, and task performance were investigated. After accounting for demographic variables and total caloric intake, increased B-vitamin intake (i.e., thiamin and folic acid) was associated with shorter reaction times ( $\left.p^{\prime} \mathrm{s}<0.05\right)$, fitness was associated with greater response accuracy $(p<0.05)$, and increased BMI was related to increased variability in reaction times $(p<0.05)$. Together, these findings suggest that aspects of health may have unique contributions on cognitive performance. Proper physical health and nutrition are imperative for effective cognitive functioning in preadolescent children. Targeted efforts aimed at health education amongst this population could ensure proper cognitive development during school-age years, providing a strong foundation throughout life.
\end{abstract}

Keywords: cognition; childhood; obesity; fitness; nutrition

\section{Introduction}

Numerous factors are important for optimal child development, in particular proper nutrition and physical activity. Childhood is a critical period for the development of lifelong habits and healthy behaviors [1]. Recently, dietary trends have shifted towards high-density processed foods, with the majority of calories now consumed from calorically dense but nutritionally poor foods $[2,3]$. In the U.S., less than one in ten children consume the recommended daily amounts of vegetables and only four in ten children eat enough fruit [4]. Poor nutrition quality during childhood is associated with long term adverse health outcomes, including some cancers and high blood pressure among others. In addition to the physical consequences of an unhealthy diet, students with lower diet quality also performed more poorly academically in terms of language and mathematics performance [5]. In addition, many children are already affected by a serious public health concern, as $19.3 \%$ of the 
pediatric population in the U.S. has obesity, including $6.1 \%$ with severe obesity and an additional $16.1 \%$ with overweight $[6,7]$. This trend presents complications to physical health and cognition, including scholastic performance [8-17]. Children with obesity have decreased cognitive performance [18], including poorer attention [8,9], increased impulsivity [10,11], decreased inhibition [12-14], decreased cognitive flexibility [15] and worse academic achievement $[16,17]$. Physical health complications associated with obesity encompass various systems such as: cardiovascular, endocrine, gastrointestinal, respiratory, musculoskeletal, and psychological [19-21]. Children with obesity also exhibit different lifestyle behaviors, for example they engage in less physical activity than their normal weight peers [22]. It is currently recommended that children achieve 60 min of moderate to-vigorous physical activity each day to optimize health benefits [23]. Unfortunately, only a quarter of all U.S. children meet the recommended activity guidelines [24,25]. This is concerning because physical activity is associated with a number of positive outcomes including reduced risk of chronic diseases and some cancers [23,26], as well as significant reductions in cardiometabolic disease risks, such as healthy weight maintenance [27], waist circumference, blood pressure, triglycerides, cholesterol, and insulin [26].

Related to physical activity, higher aerobic fitness is also inversely related to cardiovascular and metabolic risk factors [28,29]. Higher fitness during childhood is associated with advantageous cognitive function, with greater benefits observed for aspects of cognitive control. Cognitive control refers to goal-directed behavior involved in perception, memory, and action [30,31]. One of the core cognitive control processes is inhibition [32-34]. Inhibition refers to the ability to suppress task irrelevant information in the environment and withhold a prepotent or impulsive response [35]. Previous research indicates that higher fit children outperform their lower fit peers on inhibitory control tasks, with the largest differences in performance observed in the most difficult task conditions [36,37].

Inhibitory control is also implicated in childhood nutrition. After accounting for important variables such as age and IQ, increased dietary fiber intake is associated with greater accuracy on an attentional inhibition task. These findings suggest that during childhood, diet quality influences performance on challenging cognitive tasks [38]. In contrast, children who consume a diet high in saturated fats exhibit slower reaction times, as well as impaired cognitive flexibility [39], a cognitive process used in shifting, selecting attention, and modifying response. Relational memory performance is also poorer with increased consumption of saturated fatty acids and refined sugar during childhood. In contrast, greater intake of omega- 3 fatty acids is related to improved relational memory performance [40]. In addition to macronutrients, the role of micronutrients such as vitamins on physical and cognitive health is of growing interest.

B-vitamins are water soluble, perform essential roles in cellular functioning, and are critical for brain and psychological functions [41]. Much of the work examining the role of vitamins and cognition has taken place at the extremes of the lifespan. Specifically, folate (vitamin B-9) is implicated in brain development through its role in closing the neural tube during fetal development [42]. A deficiency in vitamin B-12 during pregnancy has also been associated with an increased risk of neural tube defects [43,44]. Within the last 25 years, folic acid has been added to enrich foods such as breads, flours, rice, and other grain products [45]. Deficiencies in specific vitamins may impact brain functions, with important implications for cognitive function.

There is limited and mixed research regarding B-vitamins and cognitive function in children. In Kenya, results from 554 seven-year-old children demonstrate a significant positive relationship between vitamin B-12 and riboflavin with cognitive test scores (digit span), even after controlling for important variables such as energy intake and socioeconomic status [46]. Additionally, after 37 days of supplementation with B-vitamins, 101 children in China showed increased performance on a letter selection task [47]. Further, in a large study of U.S. children, higher amounts of folate measured in blood were associated with higher reading and block design scores, while no such association was observed for vitamin B-12 [48]. In contrast, vitamin B-12 concentrations were significantly inversely 
associated with short-term memory, retrieval ability, and mental processing after controlling for hemoglobin, folate status, and height-for-age Z scores in 598 school children in India [49].

One laboratory-based cognitive task that has been used to examine obesity, physical activity, and nutrition on cognition is an inhibitory control task known as the flanker task. This task allows for interference manipulation in order to modulate inhibitory control demands [50]. The flanker task requires selective attention, or the ability to focus on certain features of the stimulus environment while ignoring others [51-53].

Current epidemiological evidence indicates that childhood obesity rates have tripled in the last 40 years [54], physical activity levels have dropped, with approximately 75\% of children failing to meet the recommended guidelines of at least 60 min of moderateto-vigorous PA every day $[23,55]$, and consumption of poor dietary patterns is on the rise, such that children consume more ultra processed foods now than 20 years ago [2]. Therefore, research is critically needed to understand the cognitive health implications related to each of these health factors. Thus, the current study examined the independent roles of fitness, obesity, and B-vitamins in a well characterized group of children to better understand the specific role of each factor on inhibitory control. It was hypothesized that healthier behaviors, including increased fitness, decreased BMI, and increased B-vitamins, would relate to better performance on a task of inhibitory control, specifically in the most challenging task conditions.

\section{Materials and Methods}

\subsection{Participants}

Participants in the study were between 8-11 years old. Exclusionary criteria included a medical diagnosis of attention deficit disorder or attention deficit hyperactivity disorder, currently taking medications for neurological disorders, specialized education due to educational or attentional disorders, or inability to complete a maximal exercise test. All participants provided written assent and their legal guardians provided written informed consent in accordance with the Institutional Review Board at Northeastern University.

Demographic information for the sample can be found in Table 1. Demographic variables included age, sex, pubertal status, parent education, household income, relative $\mathrm{VO}_{2}$ $\max (\mathrm{kg} / \mathrm{mL} / \mathrm{min}), \mathrm{VO}_{2}$ percentile, $\mathrm{BMI}\left(\mathrm{kg} / \mathrm{m}^{2}\right)$, and BMI percentile. Parents/guardians completed a measure of pubertal status to ensure prepubescence of participants [56]. Parental education for each participant was bifurcated into two groups, one group had less than an advanced degree and the other group had an advanced degree or greater. Household income was also bifurcated into two groups, greater than or less than $\$ 100,000$ annual income. The Kaufman Brief Intelligence Test Second Edition (KBIT-2; Kaufman and Kaufman, 2004) is a standardized test (with a mean $=100 \pm 15$ ) used to measure generalized intelligence (IQ) [57]. The KBIT-2 is a commercially available paper and pencil-based assessment of cognitive abilities that has been age normed. In the present study, the initial sample consisted of 88 children; however, three children were removed with IQ $<85$. Thus, the final sample consisted of 85 children.

\subsection{ASA24}

The Automated Self-Administered 24-h (ASA24) nutrition recall software was used to measure participants' dietary intake. One 24-h food recall was completed by parents with input from the child when needed. Prior research has found the ASA24 to be a feasible method for parent-proxy reporting of children's dietary intake [58]. The ASA24 is a dietary assessment tool developed by the National Cancer Institute (NCI) to collect data regarding dietary intake. An adaptation of the United States Department of Agriculture's (USDA) Automated Multiple-Pass Method (AMPM) and the Food Intake Recording Software System (FIRSSt), these "food-diaries" include a web-based tool, which records a single day food record and automatically codes the data for use in epidemiological, interventional, behavioral, or clinical research, and education. Key nutrient variables extracted for the 
present analyses included total energy $(\mathrm{kcal})$ and B-vitamins (i.e., thiamin, riboflavin, niacin, pyridoxine, folate, folic acid, and cobalamin).

Table 1. Participant demographic information (Mean \pm SE).

\begin{tabular}{|c|c|}
\hline Characteristic & \\
\hline $\mathrm{N}, \%$ female & $85,44 \%$ \\
\hline Age (years) & $9.93 \pm 0.08$ \\
\hline Household Income & $\begin{array}{c}\text { Less than } \$ 100,000 / \text { year }=38 \% \\
\$ 100,000 \text { or more } / \text { year }=62 \%\end{array}$ \\
\hline Highest Level of Mother's Education & $\begin{array}{l}\text { Less than advanced degree }=45 \% \\
\text { Advanced degree or more }=55 \%\end{array}$ \\
\hline Highest Level of Father's Education & $\begin{array}{l}\text { Less than advanced degree }=53 \% \\
\text { Advanced degree or more }=47 \%\end{array}$ \\
\hline IQ & $115.23 \pm 1.47$ \\
\hline Pubertal Status & $1.46 \pm 0.06$ \\
\hline $\mathrm{VO}_{2}$ relative $(\mathrm{kg} / \mathrm{mL} / \mathrm{min})$ & $43.44 \pm 0.77$ \\
\hline $\mathrm{VO}_{2}$ percentile & $31.81 \pm 3.28$ \\
\hline $\operatorname{BMI}\left(\mathrm{kg} / \mathrm{m}^{2}\right)$ & $17.94 \pm 0.34$ \\
\hline $\mathrm{BMI} \%$ & $56.34 \pm 3.36(27 \%$ overweight or obese $)$ \\
\hline Congruent Accuracy (\% correct) & $81.90 \pm 1.41$ \\
\hline Incongruent Accuracy (\% correct) & $66.28 \pm 1.92$ \\
\hline Accuracy Interference (\% correct) & $15.63 \pm 1.54$ \\
\hline Congruent RT (ms) & $563.52 \pm 9.47$ \\
\hline Incongruent RT (ms) & $627.11 \pm 11.23$ \\
\hline RT Interference (ms) & $63.58 \pm 5.25$ \\
\hline Congruent SDRT & $140.51 \pm 4.49$ \\
\hline Incongruent SDRT & $158.05 \pm 5.95$ \\
\hline SDRT Interference & $17.54 \pm 4.01$ \\
\hline Energy (kcal) & $1774.47 \pm 64.80$ \\
\hline Thiamin (B-1) (mg) & $1.49 \pm 0.06$ \\
\hline Riboflavin (B-2) (mg) & $1.76 \pm 0.09$ \\
\hline Niacin (B-3) (mg) & $19.32 \pm 1.17$ \\
\hline Pyridoxine (B-6) (mg) & $1.64 \pm 0.11$ \\
\hline Folate (mcg) & $378.96 \pm 20.44$ \\
\hline Folic Acid (mcg) & $202.42 \pm 17.81$ \\
\hline Cobalamin (B-12) (mcg) & $4.25 \pm 0.29$ \\
\hline
\end{tabular}

Note: IQ = generalized intelligence; $\mathrm{SES}$ = socioeconomic status; $\mathrm{VO}_{2}=$ maximal oxygen volume.

\subsection{Cardiorespiratory Fitness $\left(\mathrm{VO}_{2}\right)$}

$\mathrm{VO}_{2}$ max was used as the measure of cardiorespiratory fitness [59]. Prior to the start of the cardiorespiratory fitness test, standing height and weight measurements were taken with children wearing lightweight clothing and no shoes. Height and weight were measured using a Health o meter 500kl digital medical scale (Sunbeam Products, Boca Raton, FL, USA). An indirect calorimetry system (COSMED Quark CPET OMNIA, Concord, California) was used to measure children's maximal oxygen consumption during a modified Balke protocol [60]. After a brief warmup, children walked/ran at a constant speed on a treadmill with incline increases of $2.5 \%$ every 2 min until volitional exhaustion. During the 
test, children wore a heart rate (HR) monitor across their chest to determine their maximal heart rate. Every two minutes, ratings of perceived exertion (RPE) were assessed using the children's OMNI Scale [61], which uses a 0-10 pictorial scale to represent perceived physical effort. In addition, children's feelings were measured every two minutes on the Feeling Scale (FS). Relative peak oxygen consumption was expressed in milliliters of oxygen consumed per kilogram of bodyweight per minute. It was based upon maximal effort defined by a plateau in oxygen uptake corresponding to an increase of less than $2 \mathrm{~mL} / \mathrm{kg} / \mathrm{min}$ despite an increase in exercise workload; or a combination of the following: (1) a maximal $H R \geq 185$ beats-per-minute [60], (2) respiratory exchange ratio (RER) $\geq 1.0$ [62], and/or (3) $\mathrm{RPE} \geq 8$ [61]. Finally, based on the child's age and sex, $\mathrm{VO}_{2}$ max percentile $\left(\mathrm{VO}_{2} \mathrm{max} \%\right)$ was determined from normative data [63].

\subsection{Weight Status Assessment}

BMI was calculated as $\mathrm{kg} / \mathrm{m}^{2}$, using each participant's weight and height measured in kilograms $(\mathrm{kg})$ and meters $(\mathrm{m})$, respectively. Height and weight were measured using a Health o meter $500 \mathrm{kl}$ digital medical scale (Sunbeam Products, Boca Raton, FL) while participants were barefoot and wearing lightweight clothing. BMI percentile was calculated based on CDC growth charts for children and teens (ages 2-19 years), accounting for age and sex [64].

\subsection{Inhibition Task}

A modified version of an Eriksen flanker task was used to assess inhibitory control [50]. Participants were presented with a central target amid an array of four irrelevant flanker stimuli, which were congruent or incongruent to the central target stimulus, and asked to distinguish the centrally presented target stimulus from interfering flanking stimuli. Congruent trials consisted of an array of five stimuli facing the same direction (e.g., $>>>>>,<<<<<$ ), while incongruent trials consisted of the four flanking stimuli facing the opposite direction of the target (middle) stimulus (e.g., $>><>>,<<><<$ ). The incongruent trials require a greater amount of interference control due to perceptual interference raised by the flanking arrows pointing in the opposite direction of the central target arrow, which triggers multiple response mappings. Interference is created by manipulating the congruency of the target and flanking stimuli, such that in the congruent condition, all stimuli engender the same response mapping, whereas in the incongruent condition, the target and flanking stimuli engender alternative response mapping. Since target and flanking stimuli activate opposing action schemas, responses to congruent trials are typically faster and more accurate than incongruent trials [65]. Furthermore, incongruent trials require greater amounts of inhibitory control since target and flanking stimuli activate multiple action schemas [66]. Prior to beginning the task, participants were provided with practice trials to ensure that they understood the task and could perform at a level above $50 \%$. Participants viewed the stimuli on a computer screen positioned focally at a distance of $1 \mathrm{~m}$ using E-Prime3 software. Children completed 156 trials, with stimuli presented for a duration of $150 \mathrm{~ms}$ and a variable inter-stimulus interval of 1300, 1500 and $1700 \mathrm{~ms}$. The congruent and incongruent trials were equiprobable and were presented in a random sequence. Participants were instructed to respond using a response pad as quickly and accurately as possible with a button press on the side corresponding to the directionality of the central target stimuli amid either congruent or incongruent flanking stimuli. Performance variables were collected for congruent and incongruent trials. Accuracy was calculated as the percentage of correct responses. Mean reaction time (RT) was calculated for correct responses as the time in milliseconds (ms) from stimulus onset until response execution. Standard deviation of reaction time (SDRT) was calculated based on the RT dispersion from the mean. 


\subsection{Statistical Analysis}

Initial Pearson product-moment correlations were conducted between dependent variables from performance on the flanker task and all demographic variables (e.g., age, sex, pubertal status, income, parental education, IQ). Any variable that significantly correlated with the dependent variable was included as a covariate in the first step of the multiple linear regression analyses. Next, separate multiple hierarchical linear regression analyses were conducted for each performance variable on the flanker task. In Step 1, the dependent variables were regressed on all significantly correlated demographic variables (e.g., pubertal status, income, parental education, IQ). If no demographic variable was significantly correlated with the outcome, this step was skipped. To determine the unique contribution of each independent variable, the final step included nutrient variables, fitness and BMI, which were independently entered into Step 2 . The change in $\mathrm{R}^{2}$ values between the two steps was used to judge the independent contribution of these measures for explaining the variance in the dependent variables of interest beyond that of demographic variables.

To adjust for overall energy intake, vitamin intake was normalized to intake per $1000 \mathrm{kcal}$ within participants before analyses. Statistics were performed using SPSS 27 (IBM, Somers, NY, USA).

\section{Results}

Demographic information for the sample can be found in Table 1.

\subsection{Correlations}

Correlations between flanker variables and demographics are presented in Table 2. Age was most frequently correlated with flanker performance variables, such that older children exhibited superior flanker performance (see Table 2).

Table 2. Pearson correlations between flanker performance and demographic variables.

\begin{tabular}{|c|c|c|c|c|c|c|c|}
\hline & Age & Sex & $\begin{array}{c}\text { Pubertal } \\
\text { Timing }\end{array}$ & IQ & $\begin{array}{c}\text { Mother } \\
\text { Education }\end{array}$ & $\begin{array}{c}\text { Father } \\
\text { Education }\end{array}$ & $\begin{array}{c}\text { Household } \\
\text { Income }\end{array}$ \\
\hline $\begin{array}{l}\text { Congruent } \\
\text { Accuracy }\end{array}$ & $0.22 *$ & 0.10 & -0.03 & 0.20 & 0.13 & 0.17 & 0.01 \\
\hline $\begin{array}{c}\text { Incongruent } \\
\text { Accuracy }\end{array}$ & $0.26^{*}$ & 0.17 & -0.13 & $0.22 *$ & 0.09 & 0.17 & 0.02 \\
\hline $\begin{array}{c}\text { Accuracy } \\
\text { Interference }\end{array}$ & -0.12 & -0.12 & 0.13 & -0.10 & 0.02 & -0.05 & -0.01 \\
\hline $\begin{array}{c}\text { Congruent } \\
\text { RT }\end{array}$ & $-0.32 * *$ & -0.17 & -0.17 & -0.02 & 0.05 & -0.10 & 0.01 \\
\hline $\begin{array}{c}\text { Incongruent } \\
\text { RT }\end{array}$ & $-0.25^{*}$ & -0.21 & -0.13 & 0.02 & 0.06 & -0.07 & -0.03 \\
\hline $\begin{array}{c}\mathrm{RT} \\
\text { Interference }\end{array}$ & 0.04 & -0.16 & 0.03 & 0.09 & 0.04 & 0.02 & -0.09 \\
\hline $\begin{array}{l}\text { Congruent } \\
\text { SDRT }\end{array}$ & $-0.43^{* *}$ & 0.001 & -0.01 & -0.08 & -0.10 & -0.18 & -0.12 \\
\hline $\begin{array}{l}\text { Incongruent } \\
\text { SDRT }\end{array}$ & $-0.43^{* *}$ & -0.05 & -0.004 & 0.05 & 0.03 & -0.16 & 0.02 \\
\hline $\begin{array}{c}\text { SDRT } \\
\text { Interference }\end{array}$ & -0.16 & -0.07 & 0.01 & 0.016 & 0.15 & -0.03 & 0.16 \\
\hline
\end{tabular}

${ }^{* *}$ Correlation is significant at the 0.01 level; ${ }^{*}$ Correlation is significant at the 0.05 level. 


\subsection{Accuracy}

\subsubsection{Congruent Accuracy}

For congruent trials, the Step 1 regression analysis was significant, adjusted $\mathrm{R}^{2}=0.05$, $\mathrm{F}(1,83)=4.37, p=0.04$. In Step 2, the addition of BMI, fitness, or B-vitamins did not account for an incremental amount of variance in accuracy beyond associated descriptive variables (see Table 3).

Table 3. Congruent Accuracy Regressions.

\begin{tabular}{ccccccc}
\hline $\begin{array}{c}\text { Congruent } \\
\text { Accuracy }\end{array}$ & & ANOVA $\boldsymbol{F}$ & ANOVA $\boldsymbol{P}$ & $\boldsymbol{\Delta} \mathbf{R}^{\mathbf{2}}$ & $\mathbf{t}$ & $\boldsymbol{\beta}$ \\
\hline Step1 & Age & 4.37 & 0.04 & $0.05 *$ & 2.09 & 0.224 \\
\hline Step 2 & BMI & 2.31 & 0.11 & 0.003 & 0.54 & 0.06 \\
\hline Step 2 & $\mathrm{VO}_{2}$ max & 2.44 & 0.09 & 0.01 & 0.73 & 0.08 \\
\hline Step 2 & Thiamin (B-1) & 2.47 & 0.09 & 0.01 & 0.77 & 0.08 \\
\hline Step 2 & Riboflavin (B-2) & 2.70 & 0.07 & 0.01 & 1.02 & 0.11 \\
\hline Step 2 & Niacin (B-3) & 2.65 & 0.08 & 0.01 & -0.97 & -0.10 \\
\hline Step 2 & Pyridoxine (B-6) & 2.53 & 0.09 & 0.01 & -0.84 & -0.09 \\
\hline Step 2 & Folate & 2.64 & 0.08 & 0.01 & 0.96 & 0.10 \\
\hline Step 2 & Folic Acid & 2.24 & 0.11 & 0.002 & 0.40 & 0.04 \\
\hline Step 2 & Cobalamin (B-12) & 2.16 & 0.12 & 0.00 & 0.10 & 0.01 \\
\hline
\end{tabular}

${ }^{*} \Delta \mathrm{R}^{2}$ is significant at $p<0.05$ level.

\subsubsection{Incongruent Accuracy}

For incongruent trials, the Step 1 regression analysis was significant, adjusted $\mathrm{R}^{2}=0.14$, $F(2,82)=6.392, p=0.003$. With the addition of $\mathrm{VO}_{2} \max$, Step 2 was also significant, $\Delta \mathrm{R}^{2}=0.05, F(3,81)=6.06, p=0.001$, such that greater fitness was associated with greater incongruent accuracy, with $\mathrm{VO}_{2}$ max accounting for an incremental amount of variance in incongruent accuracy beyond the associated descriptive variables, $\beta=0.22, t(82)=2.20$, $p=0.03$. The addition of BMI and the B-vitamins did not account for an incremental amount of variance in accuracy beyond the associated descriptive variables (see Table 4).

\subsection{Mean RT}

\subsubsection{Congruent Mean RT}

For congruent trials, the Step 1 regression analysis was significant, adjusted $R^{2}=0.10$, $F(1,83)=9.14, p=0.003$. With the addition of folic acid, Step 2 was also significant, $\Delta \mathrm{R}^{2}=0.08, F(2,82)=8.71, p \leq 0.001$, such that greater dietary folic acid was associated with shorter congruent RT, with dietary folic acid accounting for an incremental amount of variance in congruent RT beyond the associated descriptive variables, $\beta=-0.28, t(82)=-2.75$, $p=0.007$. Separately, the addition of thiamin in Step 2 was also significant, $\Delta R^{2}=0.05$, $F(2,82)=7.65, p=0.001$, such that greater dietary thiamin was associated with shorter congruent RT, with dietary thiamin accounting for an incremental amount of variance in congruent RT beyond the associated descriptive variables, $\beta=-0.24, t(82)=-2.38, p=0.02$. Finally, the addition of $\mathrm{VO}_{2}$ max in Step 2 was also significant, $\Delta \mathrm{R}^{2}=0.05, F(2,82)=7.41$, $p=0.001$, such that greater fitness was associated with longer congruent $\mathrm{RT}$, with $\mathrm{VO}_{2}$ max accounting for an incremental amount of variance in congruent $\mathrm{RT}$ beyond the associated descriptive variables, $\beta=0.22, t(82)=2.28, p=0.03$. The addition of BMI and the remaining B-vitamins did not account for an incremental amount of variance in accuracy beyond associated descriptive variables (see Table 5). 
Table 4. Incongruent Accuracy Regressions.

\begin{tabular}{ccccccc}
\hline $\begin{array}{c}\text { Incongruent } \\
\text { Accuracy }\end{array}$ & & ANOVA $\boldsymbol{F}$ & ANOVA $\boldsymbol{P}$ & $\boldsymbol{\Delta} \mathbf{R}^{\mathbf{2}}$ & $\mathbf{t}$ & $\boldsymbol{\beta}$ \\
\hline Step1 & Age & 6.392 & 0.003 & $0.14^{*}$ & 2.83 & 0.29 \\
\hline Step 2 & BQ & & & & 2.49 & 0.26 \\
\hline Step 2 & $\mathrm{VO}_{2}$ max & 6.24 & 0.008 & 0.001 & -0.26 & -0.03 \\
\hline Step 2 & Thiamin (B-1) & 4.52 & 0.006 & 0.01 & 0.89 & 0.09 \\
\hline Step 2 & Riboflavin (B-2) & 4.34 & 0.007 & 0.004 & 0.59 & 0.06 \\
\hline Step 2 & Niacin (B-3) & 4.23 & 0.008 & 0.001 & -0.25 & -0.03 \\
\hline Step 2 & Pyridoxine (B-6) & 4.33 & 0.007 & 0.003 & -0.56 & -0.06 \\
\hline Step 2 & Folate FOLA & 4.33 & 0.005 & 0.01 & 0.92 & 0.10 \\
\hline Step 2 & Folic Acid FA & 4.21 & 0.008 & 0.000 & -0.10 & -0.01 \\
\hline Step 2 & Cobalamin (B-12) & 4.26 & 0.008 & 0.001 & -0.36 & -0.04 \\
\hline$\Delta \mathrm{R}^{2}$ is significant at $p<0.05$. & & & & &
\end{tabular}

$* \Delta \mathrm{R}^{2}$ is significant at $p<0.05$.

Table 5. Congruent Reaction Time Regressions.

\begin{tabular}{ccccccc}
\hline $\begin{array}{c}\text { Congruent } \\
\text { RT }\end{array}$ & & ANOVA $\boldsymbol{F}$ & ANOVA $\boldsymbol{P}$ & $\boldsymbol{\Delta} \mathbf{R}^{\mathbf{2}}$ & $\mathbf{t}$ & $\boldsymbol{\beta}$ \\
\hline Step1 & Age & 9.14 & 0.003 & $0.10^{*}$ & -3.02 & -0.23 \\
\hline Step 2 & BMI & 5.21 & 0.007 & 0.01 & -1.12 & -0.12 \\
\hline Step 2 & $\mathrm{VO}_{2}$ max & 7.41 & 0.001 & $0.05^{*}$ & 2.28 & 0.22 \\
\hline Step 2 & Thiamin (B-1) & 7.66 & 0.001 & $0.06^{*}$ & -2.38 & -0.30 \\
\hline Step 2 & Riboflavin (B-2) & 5.19 & 0.008 & 0.01 & -1.10 & -0.11 \\
\hline Step 2 & Niacin (B-3) & 5.24 & 0.007 & 0.01 & -1.14 & -0.12 \\
\hline Step 2 & Pyridoxine (B-6) & 4.75 & 0.01 & 0.005 & -0.65 & -0.07 \\
\hline Step 2 & Folate & 5.81 & 0.004 & 0.03 & -1.53 & -0.16 \\
\hline Step 2 & Folic Acid & 8.71 & 0.00 & $0.08 *$ & -2.75 & -0.28 \\
\hline Step 2 & Cobalamin (B-12) & 4.86 & 0.01 & 0.01 & -0.79 & -0.08 \\
\hline
\end{tabular}

${ }^{*} \Delta \mathrm{R}^{2}$ is significant at $p<0.05$.

\subsubsection{Incongruent Mean RT}

For incongruent trials, the Step 1 regression analysis was significant, adjusted $R^{2}=0.06$, $F(1,83)=5.30, p=0.02$. With the addition of folic acid, Step 2 was significant, $\Delta \mathrm{R}^{2}=0.08$, $F(2,82)=6.61, p=0.002$, such that greater dietary folic acid was associated with shorter incongruent RT, with dietary folic acid accounting for an incremental amount of variance in incongruent RT beyond the associated descriptive variables, $\beta=-0.28, t(82)=-2.74$, $p=0.008$. The addition of thiamin in Step 2 was also significant, $\Delta \mathrm{R}^{2}=0.08, F(2,82)=6.49$, $p=0.002$, such that greater dietary thiamin was associated with shorter incongruent RT, with dietary thiamin accounting for an incremental amount of variance in incongruent RT beyond the associated descriptive variables, $\beta=-0.28, t(82)=-2.67, p=0.008$. The addition of $\mathrm{VO}_{2} \max , \mathrm{BMI}$ and the remaining B-vitamins did not account for an incremental amount of variance in accuracy beyond associated descriptive variables (see Table 6). 
Table 6. Incongruent Reaction Time Regressions.

\begin{tabular}{ccccccc}
\hline $\begin{array}{c}\text { Incongruent } \\
\text { RT }\end{array}$ & & ANOVA $\boldsymbol{F}$ & ANOVA $\boldsymbol{P}$ & $\boldsymbol{\Delta} \mathbf{R}^{\mathbf{2}}$ & $\mathbf{t}$ & $\boldsymbol{\beta}$ \\
\hline Step1 & Age & 5.30 & 0.02 & $0.06^{*}$ & -2.30 & -0.24 \\
\hline Step 2 & BMI & 2.71 & 0.07 & 0.002 & -0.42 & -0.05 \\
\hline Step 2 & $\mathrm{VO}_{2}$ max & 4.09 & 0.02 & 0.03 & 1.66 & 0.18 \\
\hline Step 2 & Thiamin (B-1) & 6.50 & 0.002 & $0.08^{*}$ & -2.70 & -0.28 \\
\hline Step 2 & Riboflavin (B-2) & 3.42 & 0.04 & 0.02 & -1.22 & -0.13 \\
\hline Step 2 & Niacin (B-3) & 4.36 & 0.02 & 0.04 & -1.81 & -0.19 \\
\hline Step 2 & Pyridoxine (B-6) & 4.25 & 0.02 & 0.03 & -1.75 & -0.18 \\
\hline Step 2 & Folate & 3.71 & 0.03 & 0.02 & -1.43 & -0.15 \\
\hline Step 2 & Folic Acid & 6.61 & 0.002 & $0.08 *$ & -2.74 & -0.28 \\
\hline Step 2 & Cobalamin (B-12) & 3.49 & 0.04 & 0.2 & -1.28 & -0.14 \\
\hline
\end{tabular}

${ }^{*} \Delta \mathrm{R}^{2}$ is significant at $p<0.05$.

\subsection{SDRT}

\subsubsection{Congruent SDRT}

For congruent trials, the Step 1 regression analysis was significant, adjusted $R^{2}=0.11$, $F(1,83)=19.05, p \leq 0.001$. With the addition of BMI, Step 2 was also significant, $\Delta \mathrm{R}^{2}=0.07$, $F(2,82)=14.29, p \leq 0.001$, such that greater BMI was associated with greater variability in RT, with BMI accounting for an incremental amount of variance in congruent SDRT beyond the associated descriptive variables, $\beta=0.28, t(82)=2.87, p=0.005$. The addition of $\mathrm{VO}_{2} \mathrm{max}$ and the B-vitamins did not account for an incremental amount of variance in accuracy beyond the associated descriptive variables (see Table 7).

\subsubsection{Incongruent SDRT}

For incongruent trials, the Step 1 regression analysis was significant, adjusted $R^{2}=0.19$, $\mathrm{F}(1,83)=19.38, p \leq 0.001$. With the addition of BMI, Step 2 was marginally significant, $\Delta \mathrm{R}^{2}=0.04, \mathrm{~F}(2,82)=11.88, p \leq 0.06$, such that greater BMI was associated with greater SDRT, with BMI accounting for a marginal incremental amount of variance in incongruent RT variability beyond the associated descriptive variables, $\beta=0.19, t(82)=1.93, p=0.006$. The addition of $\mathrm{VO}_{2}$ max and the B-vitamins did not account for an incremental amount of variance in accuracy beyond associated descriptive variables (see Table 8).

Table 7. Congruent Standard Deviation of Reaction Time Regressions.

\begin{tabular}{ccccccc}
\hline $\begin{array}{c}\text { Congruent } \\
\text { SDRT }\end{array}$ & & ANOVA $\boldsymbol{F}$ & ANOVA $\boldsymbol{P}$ & $\boldsymbol{\Delta} \mathbf{R}^{\mathbf{2}}$ & $\mathbf{t}$ & $\boldsymbol{\beta}$ \\
\hline Step1 & Age & 19.05 & 0.000 & $0.19^{*}$ & -4.36 & -0.43 \\
\hline Step 2 & BMI & 14.49 & 0.000 & $0.07^{*}$ & 2.87 & 0.28 \\
\hline Step 2 & VO $_{2}$ max & 10.77 & 0.000 & 0.021 & -1.48 & -0.15 \\
\hline Step 2 & Thiamin (B-1) & 9.88 & 0.000 & 0.007 & 0.87 & -0.09 \\
\hline Step 2 & Riboflavin (B-2) & 9.73 & 0.000 & 0.005 & 0.72 & 0.07 \\
\hline Step 2 & Niacin (B-3) & 9.49 & 0.000 & 0.001 & 0.35 & 0.04 \\
\hline Step 2 & Pyridoxine (B-6) & 10.29 & 0.000 & 0.01 & 1.20 & 0.12 \\
\hline Step 2 & Folate & 10.09 & 0.000 & 0.01 & -1.05 & -0.10 \\
\hline Step 2 & Folic Acid & 9.84 & 0.000 & 0.007 & -0.84 & -0.08 \\
\hline Step 2 & Cobalamin (B-12) & 10.17 & 0.000 & 0.01 & 1.11 & 0.11 \\
\hline$* \mathrm{R}^{2}$ is significant at $p<0.05$. & & & & &
\end{tabular}

${ }^{*} \Delta \mathrm{R}^{2}$ is significant at $p<0.05$ 
Table 8. Incongruent Standard Deviation of Reaction Time Regressions.

\begin{tabular}{ccccccc}
\hline $\begin{array}{c}\text { Incongruent } \\
\text { SDRT }\end{array}$ & & ANOVA $\boldsymbol{F}$ & ANOVA $\boldsymbol{P}$ & $\boldsymbol{\Delta} \mathbf{R}^{\mathbf{2}}$ & $\mathbf{t}$ & $\boldsymbol{\beta}$ \\
\hline Step 1 & Age & 19.38 & 0.000 & $0.19{ }^{*}$ & -4.40 & -0.44 \\
\hline Step 2 & BMI & 11.88 & 0.000 & $0.035+$ & 1.93 & 0.19 \\
\hline Step 2 & $\mathrm{VO}_{2}$ max & 11.61 & 0.000 & 0.03 & -1.82 & -0.18 \\
\hline Step 2 & Thiamin (B-1) & 9.67 & 0.000 & 0.001 & -0.38 & -0.04 \\
\hline Step 2 & Riboflavin (B-2) & 9.56 & 0.000 & 0.000 & 0.14 & 0.01 \\
\hline Step 2 & Niacin (B-3) & 9.58 & 0.000 & 0.000 & 0.09 & 0.01 \\
\hline Step 2 & Pyridoxine (B-6) & 9.58 & 0.000 & 0.000 & -0.02 & -0.002 \\
\hline Step 2 & Folate & 11.35 & 0.000 & 0.03 & -1.69 & -0.17 \\
\hline Step 2 & Folic Acid & 10.45 & 0.000 & 0.014 & -1.19 & -0.12 \\
\hline Step 2 & Cobalamin (B-12) & 9.66 & 0.000 & 0.001 & 0.37 & 0.04 \\
\hline
\end{tabular}

${ }^{*} \Delta \mathbf{R}^{2}$ is significant at $p<0.05 ;+\Delta \mathbf{R}^{2}$ is marginally significant at $p=0.06$.

\section{Discussion}

This investigation assessed the independent effects of B-vitamin intake, aerobic fitness, and BMI using a cognitive task that manipulated inhibitory control demands. The findings from the current study complement previous research within the field via examination of behavioral outcomes in response to a selective attention task in preadolescent children in relation to a variety of health factors, including nutrition, aerobic fitness, and body composition. The merging of these health factors affords a unique opportunity to examine the specific, nuanced roles of each. Collectively, these findings provide evidence that greater intake of folic acid and thiamin, higher aerobic fitness, and lower BMI during childhood is associated with greater response accuracy, shorter RT, and less response variability during performance of an inhibitory control task that requires selective attention.

Novel to this investigation was the multifaceted analyses involving various measures of health to better understand the specificity of each on task performance. In general, higher fitness was associated with greater response accuracy in the task condition requiring greater amounts of inhibitory control (i.e., incongruent task condition). Increased BMI was associated with greater response variability. Finally, increased dietary thiamin and folic acid were related to faster responses across both conditions of the task, suggesting generalized benefits to tasks that modulate inhibitory control demand. These findings highlight the specific relations that each measure of health may have on cognition in preadolescent childhood. The results of this investigation are significant due to the nationwide increase in levels of obesity [6], declines in PA among children [67], and a growing lack of adequate sources of good nutrition [4]. Taken together, these findings suggest that future studies that modify lifestyle behaviors may have the potential improve cognition, particularly selective attention and inhibition.

One relevant lifestyle behavior is nutrition, specifically B-vitamins, as they are required for essential brain metabolic pathways and are vital for brain development and maintenance $[68,69]$. B-vitamins are important for methylation, particularly during cell repair. Further, B-vitamins are closely linked to the physiological metabolism of homocysteine, such that low levels of certain B-vitamins result in dysregulated and elevated homocysteine levels, which increase the risk for cognitive impairment in older adults [70,71]. B-vitamins appear beneficial for a variety of populations, such as adults over 40 years old and individuals with mild cognitive impairment, in terms of global cognitive function and especially for tasks of episodic memory [72]. Previous studies in older adults have linked decreased folate and thiamine with cognitive impairment and neurodegeneration [73,74]. Thiamine has an important role in energy releasing reactions in the body and is necessary for proper nervous system functioning. Food sources of thiamin include whole grains, meat, and fish [75]. 
Thiamine deficiency produces selective cell death in the brain and a loss of neurons, which have been linked to cognitive deficits. In institutionalized older adults, thiamine deficiency is associated with higher levels of depression and Alzheimer's disease [73]. Interestingly, thiamine deficient rats have a longer response time to an electric stimulus [76] and impaired cognition [77], as evidenced by impaired performance on learning, avoidance [78,79], and water maze tasks $[80,81]$. The present findings are in agreement, such that increased dietary thiamine was related to faster response times on a task of inhibition and selective attention.

Another important B-vitamin is B-9 (folate) and includes the various forms of the vitamin including folic acid, dihydrofolate, tetrahydrofolate, 5, 10-methylenetetrahydrofolate and 5-methyltetrahydrofolate [82]. Although the terms "folate" and "folic acid" are often used interchangeably, folic acid is an oxidized synthetic form of folate and is used to fortify foods and has been shown to prevent against neural tube defects $[83,84]$. Serum folate was positively associated with verbal fluency, memory recall, and letter search performance, which involves sustained attention and processing speed in a sample of 4,166 older adults in the European HAPIEE study [85]. Over a five year monitoring period, women who consumed folate levels below the recommended intake had an increased risk of mild cognitive impairment and dementia [86]. In older adults with mild cognitive impairment, supplementation with folic acid and other B-vitamins slowed the rate of brain atrophy [87]. Interestingly, our findings revealed a positive influence of consumption of folic acid, but not folate, on reaction time during both congruent and incongruent trials. As mentioned earlier, both folate and folic acid specifically have been shown to be beneficial for cognition and brain in other studies. However, one of the implications of the findings from the present work is that food sources that are fortified with folic acid, compared to foods with naturally occurring folate, may have contributed to the greater attentional and inhibitory control abilities in our sample. Alternatively, folic acid might be the largest constituent of folate consumed in the diet in the current sample. Nevertheless, our findings add to this body of literature and suggest that increased dietary folic acid is related to faster response times in children during tasks that manipulate inhibitory control and selective attention demand.

During preadolescent childhood, selective attention is crucial since it involves prolonged attention and control of one's actions [21,22], which are germane to scholastic success. Findings from the present study are in agreement with previously published data, indicating that lower fitness may relate to general impairments in cognitive control and overall brain health [88-91]. Specifically, increased aerobic fitness was related to improved performance on the task conditions requiring an upregulation of inhibitory control (i.e., the incongruent trials), suggesting that fitness may have a specific benefit to this aspect of cognition. The associations between congruent RT and fitness oppose the previously published literature, such that the present investigation found that higher fitness was related to longer response times on trials with lower inhibitory demands. There are a few possible reasons for this finding. For example, the sample was predominately lower fit and this reduced fitness range may have impacted results by not accounting for the breadth of childhood fitness. It should be further noted that data collection was impacted by the COVID-19 pandemic, which may have related to several unmeasured physical and mental health factors.

With increased BMI, children often display poorer inhibition [12]. That is, children with obesity perform more poorly on tests of inhibitory control as evidenced by longer RT across a variety of inhibitory control tasks, including the flanker [12] and Stroop [16] tasks. Such findings suggest that with higher BMI, individuals become less able to modulate inhibitory control to meet the increased task demands [15]. In the present study, these effects extend to deficits in intraindividual response variability, as measured via SDRT. SDRT reflects the within-person fluctuations in response time. These within person fluctuations in behavioral performance are a useful tool for differentiating performance during tasks requiring variable amounts of interference control. Previous research suggests that greater variability in mean RT has been observed in children relative to young adults [92,93] and in children with attention-deficit and hyperactivity disorder [94]. Prior research suggests 
that lower fit children exhibit more variable performance relative to their higher fit peers, as indicated by greater SDRT $[88,95,96]$.

In concert with the present study, previous research in children also found that greater adiposity is related to greater with-in person variability, highlighting the negative influence that excess adiposity may already exert during childhood. The current findings are in agreement and suggest an association between higher BMI and increased SDRT, which reflects more variable responses across trials. In contrast, decreases in SDRT are related to white matter tract maturation and increased functional connectivity, suggesting a neural substrate for observed differences in variability of task performance [97]. Thus, the present findings suggest that greater BMI may be a marker of decreased or delayed neural maturation during preadolescent development, including maturation of white matter integrity. Increased BMI in preadolescent childhood is also associated with lower grey and white matter volume in brain regions implicated in cognitive control and learning, suggesting an association between increased BMI and reduced cognitive outcomes [98-101]. The causal direction of the association between adiposity and cognition remains unknown; however, it could be that poorer inhibition precedes increases in BMI and may predispose a child to unhealthy behaviors that subsequently increase BMI, as research suggests that inhibitory control ability can predict weight status two and a half years later [102].

While this study adds to a growing body of literature, it is not without limitations. For example, there may be unmeasured or unobserved factors such as cognitive stimulation or parenting that are important and could confound the associations between nutrition, body composition, fitness, and cognition. These factors were not measured in the current investigation, but are important to consider in future studies. The study was cross-sectional and relies on dietary recall and, thus, does not represent long-term dietary status. However, the ASA24 is a widely used tool in nutrition research. Findings from prior studies suggest that parents are able to accurately report what their children ate and drank the day prior [103]. Since 2009, when the ASA24 was released, more than 6000 studies have registered to use ASA24 and more than 521,000 recall or record days have been collected as of January 2020 (National Cancer Institute). ASA24-2020 is the version used during the collection of dietary data for this research. Future studies should include either long term measures and/or interventions to confirm that increased dietary B-vitamins are related to improved cognitive performance. Future studies should also investigate serum levels of B-vitamins to determine if the consumed levels and the levels in the blood are both related to cognitive performance. In addition, all of the children included in this study had normal to above normal IQ and the education level of parents was high. Thus, additional research with larger samples is needed to determine if these findings extend to other groups of children.

Today's children fail to meet the federal guidelines for healthy diets, with scores nearly half of what is recommended. This puts individuals at risk of diet related adult chronic diseases [104]. In addition, children are becoming increasingly unfit and inactive, with lower fitness and higher BMI associated with increased cardiovascular risk [105], as well as decreased brain health, which have implications for cognitive and scholastic performance [36,37,88-90,106,107]. Accordingly, findings from this study add to a growing body of research indicating the beneficial relation of health factors on cognitive control and specifically selective attention and inhibitory control, in preadolescent children. Furthermore, research suggests that changes in physical activity and diet are beneficial in terms of preventing and treating childhood obesity [108] and the present findings add to this benefit and suggest benefits also extend to cognition with healthy behaviors. Given that physical inactivity, obesity, and poor nutrition are major public health concerns with a myriad of health consequences [82,83], this investigation provides critical evidence for the specific roles of different health factors on cognitive health in children. Such findings have implications for the educational environment, physical health, and brain health of today's children. 


\begin{abstract}
Author Contributions: Conceptualization, L.B.R. and C.H.H.; methodology, L.B.R., N.A.K. and C.H.H.; formal analysis, L.B.R.; investigation, L.B.R., J.N.H.W., K.M., N.E.L., A.F.K., N.A.K., C.H.H.; resources, C.H.H. and A.F.K.; data curation, L.B.R., J.N.H.W., K.M., N.E.L.; writing一original draft preparation, L.B.R.; writing-review and editing, L.B.R., J.N.H.W., K.M., N.E.L., A.F.K., N.A.K., C.H.H.; supervision, L.B.R. and C.H.H.; project administration, L.B.R., J.N.H.W., K.M., N.E.L.; funding acquisition, C.H.H. All authors have read and agreed to the published version of the manuscript.
\end{abstract}

Funding: This research was funded by the National Institute of Child Health and Human Development, grant number R01 HD094054-01.

Institutional Review Board Statement: The study was conducted according to the guidelines of the Declaration of Helsinki and approved by the Institutional Review Board (or Ethics Committee) of Northeastern University (protocol code 17-07-11, date of approval: 17 July 2017).

Informed Consent Statement: Informed consent and assent was obtained from all subjects involved in the study.

Data Availability Statement: The data presented in this study are available on request from the corresponding author. The data are not publicly available at this time as primary internal analyses are ongoing and in an effort to maintain participant confidentiality.

Conflicts of Interest: The authors declare no conflict of interest. The funding sponsors had no role in the choice of research project; design of the study; in the collection, analyses or interpretation of data; in the writing of the manuscript; or in the decision to publish the results must be declared in this section.

\title{
References
}

1. CDC, Centers for Disease Control and Prevention. Child Development Basics; CDC: Atlanta, GA, USA, 2019; pp. 1-3. Available online: https://www.cdc.gov/ncbddd/childdevelopment/facts.html (accessed on 17 September 2021).

2. Wang, L.; Martínez Steele, E.; Du, M.; Pomeranz, J.L.; O'Connor, L.E.; Herrick, K.A.; Luo, H.; Zhang, X.; Mozaffarian, D.; Zhang, F.F. Trends in consumption of ultraprocessed foods among US youths aged 2-19 years, 1999-2018. JAMA 2021, 326, 519. [CrossRef] [PubMed]

3. Sauer, C.G.; Robson, J.; Turmelle, Y.P.; Cerezo, C.S.; Loomes, K.M.; Huang, J.S.; Quiros-Tejeira, R.E.; Benkov, K.J.; Narkewicz, M.R.; Leichtner, A.; et al. North American society for pediatric gastroenterology, hepatology, and nutrition position paper on entrustable professional activities: Development of pediatric gastroenterology, hepatology, and nutrition entrustable professional activities. J. Pediatr. Gastroenterol. Nutr. 2020, 71, 136-143. [CrossRef] [PubMed]

4. CDC's Division of Nutrition, Physical Activity, and Obesity. Making Healthy Living Easier. 2021. Available online: https: //www.cdc.gov/nccdphp/dnpao/index.html (accessed on 9 November 2021).

5. Correa-Burrows, P.; Burrows, R.; Blanco, E.; Reyes, M.; Gahagan, S. Nutritional quality of diet and academic performance in Chilean students. Bull. World Health Organ. 2016, 94, 185-192. [CrossRef] [PubMed]

6. Abarca-Gómez, L.; Abdeen, Z.A.; Hamid, Z.A.; Abu-Rmeileh, N.M.; Acosta-Cazares, B.; Acuin, C.; Adams, R.J.; Aekplakorn, W.; Afsana, K.; Aguilar-Salinas, C.A.; et al. Worldwide trends in body-mass index, underweight, overweight, and obesity from 1975 to 2016: A pooled analysis of 2416 population-based measurement studies in 128.9 million children, adolescents, and adults. Lancet 2017, 390, 2627-2642. [CrossRef]

7. Ogden, C.L.; Fryar, C.D.; Martin, C.B.; Freedman, D.S.; Carroll, M.D.; Gu, Q.; Hales, C.M. Trends in obesity prevalence by race and Hispanic origin-1999-2000 to 2017-2018. JAMA 2020, 324, 1208. [CrossRef] [PubMed]

8. Cserjési, R.; Luminet, O.; Poncelet, A.-S.; Lénárd, L. Altered executive function in obesity. Exploration of the role of affective states on cognitive abilities. Appetite 2009, 52, 535-539. [CrossRef]

9. Cserjési, R.; Molnár, D.; Luminet, O.; Lénárd, L. Is there any relationship between obesity and mental flexibility in children? Appetite 2007, 49, 675-678. [CrossRef] [PubMed]

10. Braet, C.; Claus, L.; Verbeken, S.; Van Vlierberghe, L. Impulsivity in overweight children. Eur. Child Adolesc. Psychiatry 2007, 16, 473-483. [CrossRef] [PubMed]

11. Nederkoorn, C.; Coelho, J.; Guerrieri, R.; Houben, K.; Jansen, A. Specificity of the failure to inhibit responses in overweight children. Appetite 2012, 59, 409-413. [CrossRef] [PubMed]

12. Kamijo, K.; Pontifex, M.B.; Khan, N.A.; Raine, L.B.; Scudder, M.R.; Drollette, E.S.; Evans, E.M.; Castelli, D.M.; Hillman, C.H. The association of childhood obesity to neuroelectric indices of inhibition. Psychophysiology 2012, 49, 1361-1371. [CrossRef] [PubMed]

13. Kamijo, K.; Pontifex, M.B.; Khan, N.A.; Raine, L.B.; Scudder, M.R.; Drollette, E.S.; Evans, E.M.; Castelli, D.M.; Hillman, C. The negative association of childhood obesity to cognitive control of action monitoring. Cereb. Cortex 2012, 24, 654-662. [CrossRef] [PubMed]

14. Reyes, S.; Peirano, P.; Peigneux, P.; Lozoff, B.; Algarin, C. Inhibitory control in otherwise healthy overweight 10-year-old children. Int. J. Obes. 2015, 39, 1230-1235. [CrossRef] [PubMed] 
15. Lokken, K.L.; Boeka, A.G.; Austin, H.M.; Gunstad, J.; Harmon, C.M. Evidence of executive dysfunction in extremely obese adolescents: A pilot study. Surg. Obes. Relat. Dis. 2009, 5, 547-552. [CrossRef]

16. Falkner, N.H.; Neumark-Sztainer, D.; Story, M.; Jeffery, R.W.; Beuhring, T.; Resnick, M.D. Social, educational, and psychological correlates of weight status in adolescents. Obes. Res. 2001, 9, 32-42. [CrossRef]

17. Datar, A.; Sturm, R. Childhood overweight and elementary school outcomes. Int. J. Obes. 2006, 30, 1449-1460. [CrossRef] [PubMed]

18. Liang, J.; E Matheson, B.; Kaye, W.H.; Boutelle, K.N. Neurocognitive correlates of obesity and obesity-related behaviors in children and adolescents. Int. J. Obes. 2013, 38, 494-506. [CrossRef] [PubMed]

19. Grant-Guimaraes, J.; Feinstein, R.; Laber, E.; Kosoy, J. Childhood overweight and obesity. Gastroenterol. Clin. N. Am. 2016, 45, 715-728. [CrossRef]

20. Han, J.C.; Lawlor, D.A.; Kimm, S.Y. Childhood obesity. Lancet 2010, 375, 1737-1748. [CrossRef]

21. Puder, J.J.; Munsch, S. Psychological correlates of childhood obesity. Int. J. Obes. 2010, 34, S37-S43. [CrossRef] [PubMed]

22. Elmesmari, R.; Martin, A.; Reilly, J.J.; Paton, J.Y. Comparison of accelerometer measured levels of physical activity and sedentary time between obese and non-obese children and adolescents: A systematic review. BMC Pediatr. 2018, 18, 1-22. [CrossRef] [PubMed]

23. Bushman, B.A. Physical activity guidelines for Americans. ACSM's Health Fit. J. 2019, 23, 5-9. [CrossRef]

24. Troiano, R.P.; Berrigan, D.; Dodd, K.W.; Mâsse, L.C.; Tilert, T.; Mcdowell, M. Physical activity in the United States measured by accelerometer. Med. Sci. Sports Exerc. 2008, 40, 181-188. [CrossRef]

25. Dentro, K.N.; Beals, K.; Crouter, S.E.; Eisenmann, J.C.; McKenzie, T.L.; Pate, R.R.; Saelens, B.; Sisson, S.B.; Spruijt-Metz, D.; Sothern, M.S.; et al. Results from the United States' 2014 report card on physical activity for children and youth. J. Phys. Act. Health 2014, 11, S105-S112. [CrossRef] [PubMed]

26. Ekelund, U.; Luan, J.; Sherar, L.B.; Esliger, D.W.; Griew, P.; Cooper, A. Moderate to Vigorous Physical Activity and Sedentary Time and Cardiometabolic Risk Factors in Children and Adolescents. JAMA 2012, 307, 704-712. [CrossRef]

27. Janssen, I.; Katzmarzyk, P.; Boyce, W.F.; Vereecken, C.; Mulvihill, C.; Roberts, C.; Currie, C.; Pickett, W. Comparison of overweight and obesity prevalence in school-aged youth from 34 countries and their relationships with physical activity and dietary patterns. Obes. Rev. 2005, 6, 123-132. [CrossRef]

28. Ortega, F.B.; Ruiz, J.R.; Castillo, M.J.; Sjöström, M. Physical fitness in childhood and adolescence: A powerful marker of health. Int. J. Obes. 2008, 32, 1-11. [CrossRef]

29. Lang, J.; Belanger, K.; Poitras, V.; Janssen, I.; Tomkinson, G.; Tremblay, M.S. Systematic review of the relationship between $20 \mathrm{~m}$ shuttle run performance and health indicators among children and youth. J. Sci. Med. Sport 2018, 21, 383-397. [CrossRef]

30. Cohen, J.D.; Servan-Schreiber, D.; McClelland, J.L. A parallel distributed processing approach to automaticity. Am. J. Psychol. 1992, 105, 239. [CrossRef] [PubMed]

31. Kahneman, D.; Chajczyk, D. Tests of the automaticity of reading: Dilution of Stroop effects by color-irrelevant stimuli. J. Exp. Psychol. Hum. Percept. Perform. 1983, 9, 497-509. [CrossRef]

32. Diamond, A. The early development of executive functions. In Lifespan Cognition: Mechanisms of Change; Bialystok, E., Craik, F.I.M., Eds.; Oxford University Press: New York, NY, USA, 2006; pp. 70-95. [CrossRef]

33. Meyer, D.E.; Kieras, D.E. A Computational Theory of Executive Cognitive Processes and Human Multiple Task Per-formance: Part 2. Psychol. Rev. 1997, 104, 3-65. [CrossRef]

34. Norman, D.A.; Shallice, T. Attention to Action. In Consciousness and Self-Regulation; Springer: Boston, MA, USA, 1986; pp. 1-18. [CrossRef]

35. Miyake, A.; Friedman, N.P.; Emerson, M.J.; Witzki, A.H.; Howerter, A.; Wager, T.D. The unity and diversity of executive functions and their contributions to complex "Frontal Lobe" tasks: A latent variable analysis. Cogn. Psychol. 2000, 41, 49-100. [CrossRef]

36. Pontifex, M.B.; Raine, L.B.; Johnson, C.R.; Chaddock, L.; Voss, M.W.; Cohen, N.J.; Kramer, A.F.; Hillman, C.H. Cardiorespiratory fitness and the flexible modulation of cognitive control in preadolescent children. J. Cogn. Neurosci. 2011, 23, 1332-1345. [CrossRef] [PubMed]

37. Voss, M.; Chaddock, L.; Kim, J.; VanPatter, M.; Pontifex, M.; Raine, L.; Cohen, N.; Hillman, C.; Kramer, A. Aerobic fitness is associated with greater efficiency of the network underlying cognitive control in preadolescent children. Neuroscience 2011, 199, 166-176. [CrossRef]

38. Khan, N.A.; Raine, L.B.; Drollette, E.S.; Scudder, M.R.; Kramer, A.; Hillman, C. Dietary fiber is positively associated with cognitive control among prepubertal children. J. Nutr. 2014, 145, 143-149. [CrossRef]

39. Khan, N.A.; Raine, L.B.; Drollette, E.S.; Scudder, M.R.; Hillman, C. The relation of saturated fats and dietary cholesterol to childhood cognitive flexibility. Appetite 2015, 93, 51-56. [CrossRef]

40. Baym, C.L.; Khan, N.A.; Monti, J.M.; Raine, L.B.; Drollette, E.S.; Moore, R.D.; Scudder, M.R.; Kramer, A.; Hillman, C.; Cohen, N.J. Dietary lipids are differentially associated with hippocampal-dependent relational memory in prepubescent children. Am. J. Clin. Nutr. 2014, 99, 1026-1032. [CrossRef] [PubMed]

41. Kennedy, D.O. B vitamins and the brain: Mechanisms, dose and efficacy-A review. Nutrients 2016, 8, 68. [CrossRef] [PubMed]

42. Cockcroft, D.W.; Nair, P. Methacholine test and the diagnosis of asthma. J. Allergy Clin. Immunol. 2012, 130, 556-557. [CrossRef]

43. Villalpando, S. Discussion: Effects of folate and vitamin B12 deficiencies during pregnancy on fetal, infant, and child development. Food Nutr. Bull. 2008, 29, S112-S115. [CrossRef] 
44. Refsum, H. Folate, vitamin B12 and homocysteine in relation to birth defects and pregnancy outcome. Br. J. Nutr. 2001, 85, S109-S113. [CrossRef]

45. US. Department of Health and Human Services, Food and Drug Administration. Food Standards: Amendment of Standards of Identity for Enriched Grain Products to Require Addition of Folic Acid, 1996. Fed. Regist. Available online: https://ci.nii.ac.jp/ naid/10026114656 (accessed on 7 September 2021).

46. Gewa, C.A.; Weiss, R.E.; Bwibo, N.O.; Whaley, S.; Sigman, M.; Murphy, S.P.; Harrison, G.; Neumann, C.G. Dietary micronutrients are associated with higher cognitive function gains among primary school children in rural Kenya. Br. J. Nutr. 2008, 101, 1378-1387. [CrossRef] [PubMed]

47. Jiang, Y.Y. Effect of B vitamins-fortified foods on primary school children in Beijing. Asia Pac. J. Public Health 2006, 18, 21-25. [CrossRef] [PubMed]

48. Nguyen, C.T.; Gracely, E.J.; Lee, B.K. Serum folate but not vitamin B-12 concentrations are positively associated with cognitive test scores in children aged 6-16 years. J. Nutr. 2013, 143, 500-504. [CrossRef]

49. Eilander, A.; Muthayya, S.; van der Knaap, H.; Srinivasan, K.; Thomas, T.; Kok, F.J.; Kurpad, A.V.; Osendarp, S.J.M. Undernutrition, fatty acid and micronutrient status in relation to cognitive performance in Indian school children: A cross-sectional study. Br. J. Nutr. 2009, 103, 1056-1064. [CrossRef] [PubMed]

50. Eriksen, B.A.; Eriksen, C.W. Effects of noise letters upon the identification of a target letter in a nonsearch task. Percept. Psychophys. 1974, 16, 143-149. [CrossRef]

51. Diamond, A. Executive Functions. Annu. Rev. Psychol. 2013, 64, 135-168. [CrossRef] [PubMed]

52. Posner, M.; DiGirolamo, G. Executive attention: Conflict, target detection, and cognitive control. In The Attentive Brain; MIT Press: Cambridge, MA, USA, 1998.

53. Theeuwes, J. Top-down and bottom-up control of visual selection. Acta Psychol. 2010, 135, 77-99. [CrossRef] [PubMed]

54. Ogden, C.L.; Carroll, M.D.; Kit, B.K.; Flegal, K.M. Prevalence of obesity and trends in body mass index among US children and adolescents, 1999-2010. JAMA J. Am. Med. Assoc. 2012, 307, 483-490. [CrossRef] [PubMed]

55. Kohl, H.W.; Craig, C.L.; Lambert, E.V.; Inoue, S.; Alkandari, J.R.; Leetongin, G.; Kahlmeier, S.; Andersen, L.B.; Bauman, A.E.; Blair S.N.; et al. The pandemic of physical inactivity: Global action for public health. Lancet 2012, 380, 294-305. [CrossRef]

56. Taylor, S.J.; Whincup, P.; Hindmarsh, P.C.; Lampe, F.; Odoki, K.; Cook, D. Performance of a new pubertal self-assessment questionnaire: A preliminary study. Paediatr. Périnat. Epidemiol. 2001, 15, 88-94. [CrossRef] [PubMed]

57. Alan, P.; Kaufman, S.; Kaufman, N.L. Kaufman Test of Educational Achievement, 2nd ed.; Pearson: London, UK, 2004.

58. Sharpe, I.; Kirkpatrick, S.I.; Smith, B.T.; Keown-Stoneman, C.D.G.; Omand, J.; Vanderhout, S.; Maguire, J.L.; Birken, C.S.; Anderson, L.N. Automated self-administered 24-H dietary assessment tool (ASA24) recalls for parent proxy-reporting of children's intake (>4 years of age): A feasibility study. Pilot Feasibility Stud. 2021, 7, 1-10. [CrossRef] [PubMed]

59. Winsley, R.J.; Armstrong, N.; Middlebrooke, A.R.; Ramos-Ibanez, N.; Williams, C.A. Aerobic fitness and visceral adipose tissue in children. Acta Paediatr. 2006, 95, 1435-1438. [CrossRef] [PubMed]

60. American College of Sports Medicine. American College of Sports Medicine's Guidelines for Exercise Testing and Prescription/American College of Sports Medicine, 9th ed.; Lippincott Williams \& Wilkins: Philadelphia, PA, USA, 2014.

61. Utter, A.C.; Robertson, R.J.; Nieman, D.C.; Kang, J. Children's OMNI scale of perceived exertion: Walking/running evaluation. Med. Sci. Sports Exerc. 2002, 34, 139-144. [CrossRef]

62. Bar-Or, O. Pediatric Sports Medicine for the Practitioner: From Physiologic Principles to Clinical Applications; Springer Science \& Business Media: New York, NY, USA, 1983; Available online: http:/ /download.springer.com/static/pdf/491/bfm\%3A978-1-4612-5593-2 \%2F1.pdf?originUrl=http:/ /link.springer.com/book/bfm:978-1-4612-5593-2/1\&token2=exp=1449331700 \{\}acl=/static/pdf/491/ bfm\%253A978-1-4612-5593-2\%252F1.pdf?originUrl=http\%3A\%2F\%2Flink.springer (accessed on 5 December 2021).

63. Shvartz, E.; Reibold, R.C. Aerobic fitness norms for males and females aged 6 to 75 years: A review. Aviat. Space Environ. Med. 1990, 61, 3-11. [PubMed]

64. Centers for Disease Control and Prevention. BMI Percentile Calculator for Child and Teen. Available online: https://www.cdc gov/healthyweight/bmi/calculator.html (accessed on 2 January 2021).

65. Eriksen, C.W.; Schultz, D.W. Information processing in visual search: A continuous flow conception and experimental results. Percept. Psychophys. 1979, 25, 249-263. [CrossRef] [PubMed]

66. Spencer, K.M.; Coles, M.G.H. The lateralized readiness potential: Relationship between human data and response activation in a connectionist model. Psychophysiology 1999, 36, 364-370. [CrossRef]

67. Ng, S.W.; Popkin, B.M. Time use and physical activity: A shift away from movement across the globe. Obes. Rev. 2012, 13, 659-680. [CrossRef] [PubMed]

68. Ke, Z.-J.; Gibson, G.E. Selective response of various brain cell types during neurodegeneration induced by mild impairment of oxidative metabolism. Neurochem. Int. 2004, 45, 361-369. [CrossRef]

69. Van De Rest, O.; Van Hooijdonk, L.W.A.; Doets, E.; Schiepers, O.J.G.; Eilander, A.; de Groot, L. B vitamins and n-3 fatty acids for brain development and function: Review of human studies. Ann. Nutr. Metab. 2012, 60, 272-292. [CrossRef] [PubMed]

70. Tucker, K.L.; Qiao, N.; Scott, T.; Rosenberg, I.; Spiro, I.A. High homocysteine and low B vitamins predict cognitive decline in aging men: The veterans affairs normative aging study. Am. J. Clin. Nutr. 2005, 82, 627-635. [CrossRef]

71. Reynolds, E. Vitamin B12, folic acid, and the nervous system. Lancet Neurol. 2006, 5, 949-960. [CrossRef] 
72. Suh, S.W.; Kim, H.S.; Han, J.H.; Bin Bae, J.; Oh, D.J.; Kim, K.W. Efficacy of vitamins on cognitive function of non-demented people: A systematic review and meta-analysis. Nutrients 2020, 12, 1168. [CrossRef]

73. Pepersack, T.; Garbusinski, J.; Robberecht, J.; Beyer, I.; Willems, D.; Fuss, M. Clinical relevance of thiamine status amongst hospitalized elderly patients. Gerontology 1999, 45, 96-101. [CrossRef] [PubMed]

74. Gibson, G.E.; Hirsch, J.A.; Fonzetti, P.; Jordan, B.D.; Cirio, R.T.; Elder, J. Vitamin B1 (thiamine) and dementia. Ann. N. Y. Acad. Sci. 2016, 1367, 21-30. [CrossRef] [PubMed]

75. Bettendorff, L. Thiamin. In Present Knowledge Nutrition, 10th ed.; Erdman, J.W., Macdonald, I.A., Zeisel, S.H., Eds.; Wiley-Blackwell: Washington, DC, USA, 2012; pp. 261-279.

76. Terasawa, M.; Nakahara, T.; Tsukada, N.; Sugawara, A.; Itokawa, Y. The relationship between thiamine deficiency and performance of a learning task in rats. Metab. Brain Dis. 1999, 14, 137-148. [CrossRef] [PubMed]

77. Ciccia, R.M.; Langlais, P.J. An examination of the synergistic interaction of ethanol and thiamine deficiency in the development of neurological signs and long-term cognitive and memory impairments. Alcohol. Clin. Exp. Res. 2000, 24, 622-634. [CrossRef] [PubMed]

78. Nakagawasai, O.; Tadano, T.; Hozumi, S.; Tan-No, K.; Niijima, F.; Kisara, K. Immunohistochemical estimation of brain choline acetyltransferase and somatostatin related to the impairment of avoidance learning induced by thiamine deficiency. Brain Res. Bull. 2000, 52, 189-196. [CrossRef]

79. Langlais, P.J.; Savage, L.M. Thiamine deficiency in rats produces cognitive and memory deficits on spatial tasks that correlate with tissue loss in diencephalon, cortex and white matter. Behav. Brain Res. 1995, 68, 75-89. [CrossRef]

80. Langlais, P.J.; Mandel, R.J.; Mair, R.G. Diencephalic lesions, learning impairments, and intact retrograde memory following acute thiamine deficiency in the rat. Behav. Brain Res. 1992, 48, 177-185. [CrossRef]

81. Carvalho, F.M.; Pereira, S.R.C.; Pires, R.G.W.; Ferraz, V.P.; Romano-Silva, M.; Oliveira-Silva, I.F.; Ribeiro, A.M. Thiamine deficiency decreases glutamate uptake in the prefrontal cortex and impairs spatial memory performance in a water maze test. Pharmacol. Biochem. Behav. 2006, 83, 481-489. [CrossRef]

82. Crider, K.S.; Bailey, L.B.; Berry, R.J. Folic acid food fortification-Its history, effect, concerns, and future directions. Nutrients 2011, 3, 370-384. [CrossRef] [PubMed]

83. De Wals, P.; Tairou, F.; Van Allen, M.I.; Uh, S.-H.; Lowry, R.B.; Sibbald, B.; Evans, J.A.; Van den Hof, M.C.; Zimmer, P.; Crowley, M.; et al. Reduction in neural-tube defects after folic acid fortification in Canada. N. Engl. J. Med. 2007, 357, 135-142. [CrossRef]

84. Berry, R.; Li, Z.; Erickson, J.D.; Li, S.; Moore, C.A.; Wang, H.; Mulinare, J.; Zhao, P.; Wong, L.-Y.C.; Gindler, J.; et al. Prevention of neural-tube defects with folic acid in China. N. Engl. J. Med. 1999, 341, 1485-1490. [CrossRef] [PubMed]

85. Horvat, P.; Gardiner, J.; Kubinova, R.; Pajak, A.; Tamosiunas, A.; Schöttker, B.; Pikhart, H.; Peasey, A.; Jansen, E.; Bobak, M. Serum folate, vitamin B-12 and cognitive function in middle and older age: The HAPIEE study. Exp. Gerontol. 2016, 76, 33-38. [CrossRef]

86. Agnew-Blais, J.C.; Wassertheil-Smoller, S.; Kang, J.H.; Hogan, P.E.; Coker, L.H.; Snetselaar, L.G.; Smoller, J.W. Folate, Vitamin B-6, and vitamin B-12 intake and mild cognitive impairment and probable dementia in the women's health initiative memory study. $J$. Acad. Nutr. Diet. 2014, 115, 231-241. [CrossRef]

87. Jernerén, F.; Elshorbagy, A.; Oulhaj, A.; Smith, S.M.; Refsum, H.; Smith, D. Brain atrophy in cognitively impaired elderly: The importance of long-chain $\omega-3$ fatty acids and B vitamin status in a randomized controlled trial. Am. J. Clin. Nutr. 2015, 102, 215-221. [CrossRef] [PubMed]

88. Wu, C.-T.; Pontifex, M.B.; Raine, L.B.; Chaddock, L.; Voss, M.W.; Kramer, A.F.; Hillman, C.H. Aerobic fitness and response variability in preadolescent children performing a cognitive control task. Neuropsychology 2011, 25, 333-341. [CrossRef] [PubMed]

89. Kao, S.-C.; Drollette, E.S.; Scudder, M.R.; Raine, L.B.; Westfall, D.R.; Pontifex, M.B.; Hillman, C.H. Aerobic fitness is associated with cognitive control strategy in preadolescent children. J. Mot. Behav. 2016, 49, 150-162. [CrossRef] [PubMed]

90. Chaddock, L.; Erickson, K.I.; Prakash, R.S.; VanPatter, M.; Voss, M.W.; Pontifex, M.; Raine, L.B.; Hillman, C.; Kramer, A. Basal ganglia volume is associated with aerobic fitness in preadolescent children. Dev. Neurosci. 2010, 32, 249-256. [CrossRef]

91. Scudder, M.R.; Lambourne, K.; Drollette, E.S.; Herrmann, S.D.; Washburn, R.A.; Donnelly, J.E.; Hillman, C.H. Aerobic capacity and cognitive control in elementary school-age children. Med. Sci. Sports Exerc. 2014, 46, 1025-1035. [CrossRef] [PubMed]

92. McAuley, T.; Yap, M.; Christ, S.E.; White, D.A. Revisiting inhibitory control across the life span: Insights from the ex-gaussian distribution. Dev. Neuropsychol. 2006, 29, 447-458. [CrossRef]

93. Williams, B.R.; Hultsch, D.F.; Strauss, E.H.; Hunter, M.A.; Tannock, R. Inconsistency in reaction time across the life span. Neuropsychology 2005, 19, 88-96. [CrossRef]

94. Kofler, M.J.; Rapport, M.D.; Sarver, D.E.; Raiker, J.; Orban, S.A.; Friedman, L.M.; Kolomeyer, E.G. Reaction time variability in ADHD: A meta-analytic review of 319 studies. Clin. Psychol. Rev. 2013, 33, 795-811. [CrossRef] [PubMed]

95. Moore, R.D.; Wu, C.-T.; Pontifex, M.B.; O'Leary, K.C.; Scudder, M.R.; Raine, L.B.; Johnson, C.R.; Hillman, C.H. Aerobic fitness and intra-individual variability of neurocognition in preadolescent children. Brain Cogn. 2013, 82, 43-57. [CrossRef]

96. Raine, L.B.; Kao, S.-C.; Pindus, D.; Westfall, D.R.; Shigeta, T.T.; Logan, N.; Cadenas-Sanchez, C.; Li, J.; Drollette, E.S.; Pontifex, M.B.; et al. A large-scale reanalysis of childhood fitness and inhibitory control. J. Cogn. Enhanc. 2018, 2, 170-192. [CrossRef]

97. Tamnes, C.K.; Fjell, A.M.; Westlye, L.T.; Østby, Y.; Walhovd, K.B. Becoming consistent: Developmental reductions in intraindividual variability in reaction time are related to white matter integrity. J. Neurosci. 2012, 32, 972-982. [CrossRef] [PubMed] 
98. Yau, P.L.; Kang, E.H.; Javier, D.C.; Convit, A. Preliminary evidence of cognitive and brain abnormalities in uncomplicated adolescent obesity. Obesity 2014, 22, 1865-1871. [CrossRef]

99. Alarcón, G.; Ray, S.; Nagel, B.J. Lower working memory performance in overweight and obese adolescents is mediated by white matter microstructure. J. Int. Neuropsychol. Soc. 2015, 22, 281-292. [CrossRef] [PubMed]

100. Alosco, M.L.; Stanek, K.M.; Galioto, R.; Korgaonkar, M.; Grieve, S.; Brickman, A.M.; Spitznagel, M.B.; Gunstad, J. Body mass index and brain structure in healthy children and adolescents. Int. J. Neurosci. 2013, 124, 49-55. [CrossRef] [PubMed]

101. Ou, X.; Andres, A.; Pivik, R.; Cleves, M.A.; Badger, T.M. Brain gray and white matter differences in healthy normal weight and obese children. J. Magn. Reson. Imaging 2015, 42, 1205-1213. [CrossRef]

102. Graziano, P.A.; Calkins, S.D.; Keane, S.P. Toddler self-regulation skills predict risk for pediatric obesity. Int. J. Obes. 2010, 34, 633-641. [CrossRef] [PubMed]

103. Wallace, A.; Kirkpatrick, S.I.; Darlington, G.; Haines, J. Accuracy of parental reporting of preschoolers' dietary intake using an online self-administered 24-h recall. Nutrients 2018, 10, 987. [CrossRef] [PubMed]

104. Banfield, E.C.; Liu, Y.; Davis, J.S.; Chang, S.; Frazier-Wood, A.C. Poor adherence to US dietary guidelines for children and adolescents in the National health and nutrition examination survey population. J. Acad. Nutr. Diet. 2015, 116, 21-27. [CrossRef] [PubMed]

105. Brage, S.; Wedderkopp, N.; Ekelund, U.; Franks, P.W.; Wareham, N.J.; Andersen, L.B.; Froberg, K. Features of the metabolic syndrome are associated with objectively measured physical activity and fitness in Danish children: The European youth heart study (EYHS). Diabetes Care 2004, 27, 2141-2148. [CrossRef] [PubMed]

106. Moore, R.D.; Drollette, E.S.; Scudder, M.R.; Ebharij, A.; Hillman, C.H. The influence of cardiorespiratory fitness on strategic, behavioral, and electrophysiological indices of arithmetic cognition in preadolescent children. Front. Hum. Neurosci. 2014, 8, 258. [CrossRef] [PubMed]

107. Chaddock-Heyman, L.; Erickson, K.I.; Kienzler, C.; King, M.; Pontifex, M.B.; Raine, L.B.; Hillman, C.; Kramer, A. The role of aerobic fitness in cortical thickness and mathematics achievement in preadolescent children. PLoS ONE 2015, 10, e0134115. [CrossRef]

108. Mead, E.; Brown, T.; Rees, K.; Azevedo, L.B.; Whittaker, V.; Jones, D.; Olajide, J.; Mainardi, G.M.; Corpeleijn, E.; O’Malley, C.; et al. Diet, physical activity and behavioural interventions for the treatment of overweight or obese children from the age of 6 to 11 years. Cochrane Database Syst. Rev. 2017, 2017, CD012651. [CrossRef] [PubMed] 